\title{
HUKUM MELAKSANAKAN SALAT ID SECARA PERSONAL (MUNFARID) (SEBUAH SOLUSI PELAKSANAAN SALAT ID DI MASA WABAH COVID-19)
}

\author{
Akhmad Hanafi Dain Yunta \\ Sekolah Tinggi Ilmu Islam dan Bahasa Arab (STIBA) Makassar \\ Email: ahmadhanafi@stiba.ac.id \\ Asri \\ Sekolah Tinggi Ilmu Islam dan Bahasa Arab (STIBA) Makassar \\ Email: asridaeng1@stiba.ac.id
}

\begin{abstract}
Keywords :
ABSTRACT

Id prayer, personal, excuse, covid-19

Id prayer is one of the prayers recommended to be done in congregation, but in abnormal conditions sometimes Muslims are prevented from conducting it in congregation, so it must be conducted in their homes either individually (munfarid) or in congregation with family members in one house. This study aimed to recognize the law of conducting id prayer at home in the midst of covid-19 outbreak. In this study the author employed library research method with a juridical normative approach to get accurate results from different perspectives described in numbers of works by classic scholars to be applied in the current situations. The results show that Id prayer may be done at home either individually or in congregation with family members in order to avoid the spread and transmission of covid-19.
\end{abstract}

Kata kunci :

salat id, munfarid, uzur, covid-19

\section{ABSTRAK}

Salat Id (hari raya) adalah salah satu di antara salat-salat yang disunnahkan untuk dikerjakan secara berjama'ah, namun dalam kondisi yang tidak normal terkadang umat Islam terhalang untuk melaksanakannya secara berjama'ah, sehingga terpaksa dikerjakan di rumah masing-masing, baik dikerjakan secara sendiri-sendiri (munfarid) atau berjama'ah dengan anggota keluarga yang berada dalam dalam satu rumah. Penelitian ini bertujuan untuk menggali hukum melaksanakan salat Id di rumah masing-masing di tengah mewabahnya covid 19. Dalam penelitian ini penulis menggunakan metode library research dengan pendekatan normatif yuridis untuk mendapatkan hasil yang akurat dari berbagai macam sudut pandang yang telah dijelaskan dalam berbagai karya para ulama klasik lalu diaplikasikan untuk kondisi sekarang. Hasil penelitian menunjukkan bahwa salat Id boleh dikerjakan dirumah masing-masing, baik sendiri-sendiri ataupun berjama'ah dengan keluarga yang serumah demi untuk menghindari penyebaran dan penularan covid 19. 


\section{PENDAHULUAN}

Ibadah Id (hari raya) merupakan salah satu diantara momentum yang sangat berharga dalam kehidupan seorang muslim secara pribadi dan kaum muslimin secara umum. Momentum Id bukan hanya terbatas kepada pelaksanaan ibadah-ibadah yang mulia di hari tersebut, lebih dari itu ia adalah momentum kebersamaan, kebahagian dan sarana untuk mempererat kesatuan dan ukhuwah umat Islam.

Pelaksanaan salat Id dengan berbagai elemen perkara-perkara terkait di dalamnya mendapatkan porsi yang lumayan luas dalam literatur ulama baik klasik begitu juga literatur kontemporer. Diantara pembahasan yang diangkat adalah berkaitan dengan tempat pelaksanaan salat Id disertai persyaratan jamaah dan jumlah dalam pelaksanaannya. Para ulama menjelaskan bahwa diantara hal yang ditekankan dalam pelaksanaan salat Id adalah pelaksanaanya secara berjamaah di tempat yang luas baik di lapangan terbuka atau di masjid-masjid yang dapat menampung jumlah jamaah yang banyak. Syeikh Abdullah al-Bassam -Rahimahullah- berkata:

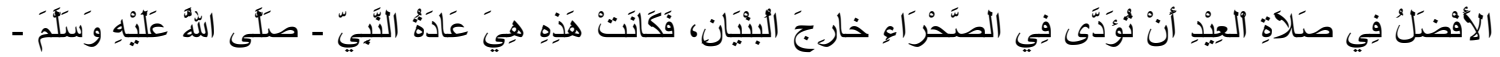

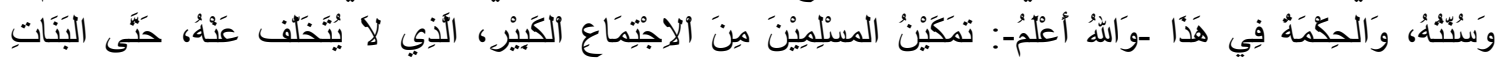

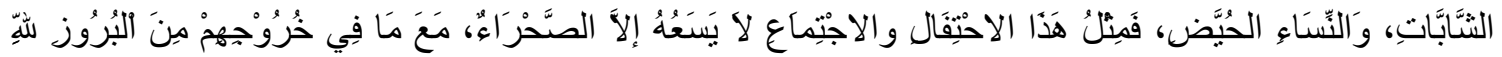

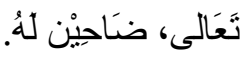

Terjemahannya: "Yang utama pelaksanaan salat id di tempat terbuka di luar kota, ini merupakan kebiasaan dan sunnah Nabi -Shallallahu'alaihiwasallam-. Dan hikmahnya adalah: memberikan kesempatan kepada kaum muslimin untuk berkumpul dalam jumlah besar di mana tidak satupun yang ketinggalan, bahkan gadis-gadis belia, wanita haidh (diperintahkan untuk keluar). Dan tempat yang paling sesuai untuk perkumpulan dan perayaan ini adalah tempat terbuka (lapangan), di samping (keistimewaan) keluarnya dan menampakkan keagungan semata-mata karena Allah." ${ }^{1}$ (Tawdhih al-Ahkaam 3/ 55).

Diantara hal yang penting dikaji menyikapi kasus kekinian kita dengan merebaknya virus Corona Covid 19, adalah penerapan kebijakan pembatasan sosial (social distancing) dan bahkan pembatasan fisik (physical distancing) bahkan disebagian tempat kebijakan ini telah diterjemahkan dalam format pemberlakuan Pembatasan Sosial Berskala Besar dan Kecil (PSBB dan PSBK). Hal ini setidaknya meniscayakan pembahasan hal-hal yang berkaitan dengan pelaksanaan ibadah yang dilakukan berjamaah dalam satu tempat baik dalam jumlah besar ataupun kecil.

Para ulama baik personal ataupun kolektif lewat lembaga-lembaga yang berkompeten sejak merebaknya kasus Covid 19 yang telah memakan korban ribuan orang diberbagai Negara, telah mengeluarkan beberapa himbauan umum bahkan fatwa berkaitan dengan pelaksanaan salat Jum'at yang diganti dengan salat Dzuhur dan salat

\footnotetext{
${ }^{1}$ Abdullah bin Abdurrahman bin Soleh Al Bassam Al Tamimiy, Taudih Al Ahkam Min Bulughi Al Maram, Jilid III (Makkah Al Mukarramah, Maktabah Al Asadiy, Cet. Ke-5, 1423H/2003M) h. 44
} 
berjamaah lima waktu di masjid dialihkan dan dilakukan di rumah masing-masing. Maka apakah hal ini bisa dilakukan pada salat Id, apakah bisa dilakukan di rumah atau dilakukan secara pribadi-pribadi bersendirian atau tidak?, termasuk di dalamnya ibadah-ibadah lain yang dilakukan menyertai pelaksaan salat Id itu. Mudah-mudahan tulisan ini bisa memberikan sedikit pencerahan berkaitan dengan pandangan para ulama tentang pelaksanaan salat Id secara personal dan tidak melakukannya secara berjamaah seperti apa yang disebutkan oleh para ulama dan kelaziman yang dilakukan oleh kaum muslimin.

Dalam tulisan ini ada beberapa permasalahan yang akan dibahas, yakni pada perkara-perkara sebagai berikut :

1. Bagaimana hukum salat Id secara personal (munfarid) Perspektif ulama?

2. Bagaimana Hukum Pelaksanaan Salat Id secara personal dan terbatas di masa Covid 19?

3. Bagaimana Tata cara pelaksanaan Salat Id dan ibadah yang berkaitan di rumah dan dalam kondisi terbatas?

\section{PEMBAHASAN}

\section{Pandangan ulama berkaitan dengan pelaksanaan salat Id secara personal (munfarid)}

Bolehkah melaksanakan salat Id secara personal dan tidak berjamaah?. Dari penulusuran berbagai literatur fikih klasik, penulis simpulkan secara umum bahwa dari empat mazhab muktabar yang dijadikan sebagi acuan ulama, maka hanya mazhab Hanafiyah yang tidak membolehkan pelaksanaan salat Id secara sendiri-sendiri. AlImam Mulla Khusru berkata:

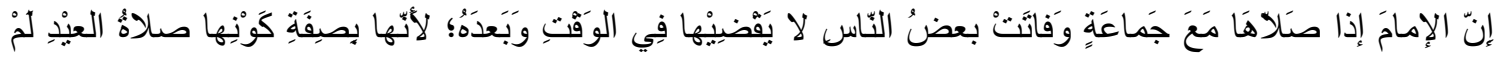

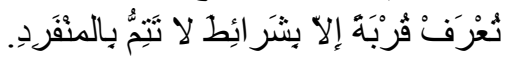

Terjemahannya: "Bahwasanya Imam jika telah melaksanakan salat Id bersama jamaah sementara sebagian orang terlambat melakukannya maka tidak perlu bagi mereka (yang terlambat) untuk mengqadha baik pada saat itu ataupun setelahnya, karena salat ini disifatkan sebagai salat Id tidak dikenal sebagai sebuah ketaatan kecuali dengan persyaratan-persyaratan yang tidak dapat dilakukan oleh personal (munfarid). ${ }^{2}$ (Durar al-Hukkam Syarh Ghurar al-Ahkam 1/ 144)

Penjelasan di atas meskipun dalam permasalahan apakah orang yang terlambat dan tidak mendapatkan salat bersama jamaah kaum muslimin akan tetapi dari sisi alasandan pendalilan dikemukakan menjadi jelas bahwa dalam mazhab Hanafiyah salat Id memiliki beberapa persyaratan dimana persyaratan-persyaratan tersebut tidak dapat dilaksanakan sekiranya salat ini dilakukan secara personal perseorangan. Adapun syarat-syarat tersebut dapat langsung ditelusuri dalam literatur-literatur mazhab Hanafiyah. Alasan yang dikemukakan dalam hal ini adalah pelaksanaan salat Id

\footnotetext{
2'Muhammad bin Framurz Mulla Khusru, Durar al-Hukkam Syarh Ghurar al-Ahkam, Jilid I (... Dar Ihya' Al Kutub Al Arabiyyah, t.t.t) h.144.
} 
dikiyaskan dengan salat Jum'at, di mana salah satu syaratnya adalah pelaksanaan Jum'at bagi yang diwajibkan dilakukan secara berjamaah, maka seperti itupula yang berlaku untuk salatId. ${ }^{3}$ (al-Muhith al-Burhaniy, 2/ 112)

Adapun jumhur ulama dalam hal ini ketiga mazhab muktabar lainnya; Malikiyah, Syafi'iyyah dan Hanabilah maka yang masyhur dari pendapat ulama-ulama mazhab tersebut adalah bahwa secara umum salat ini bisa dilakukan secara personal dan tidak dipersyaratkan untuk dilaksanakan berjamaah.

Dalam mazhab Malikiyah disebutkan bahwa pendapat yang kuat dalam mazhab adalah jika seseorang yang terlambat dan tidak sempat melaksanakan salat Id berjamaah atau terkendala uzur maka mereka diperintahkan untuk melaksanakan salat Id ini secara personal dan bahkan tidak melakukannya secara berjamaah. Dalam kitab Manh al-Jalil dijelaskan:

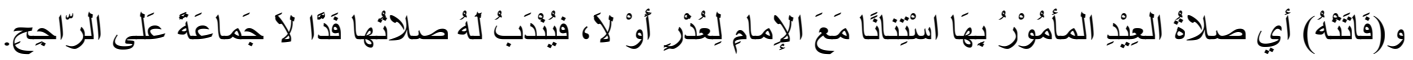

Terjemahannya: "Siapa saja yang disunnahkan untuk melaksanakan salat Id bersama Imam dan ia tidak mendapatinya karena ada uzur atau tidak, maka pendapat yang rajih (dalam mazhab) ia dianjurkan untuk melakukannya secara bersendirian dan tidak melakukannya secara berjamaah”. ${ }^{4}$ (Manh al-Jalil syarh Mukhtasar al-Khalil 1/ 467).

Mazhab Malikiyah menurut pendapat yang rajih, secara tegas menetapkan bolehnya salat Id secara personal bahkan tidak dianjurkan melaksanakannya secara berjamaah bagi yang memiliki uzur yang menyebabkan ia terhalang melaksanakannya bersama kaum muslimin lainnya.

Menurut pendapat muktamad dalam Mazhab Syafiiyah dan Hanabilah bahwa secara prinsip pelaksanaan salat Id dapat dilakukan secara personal (munfarid). AnNawawiy berkata:

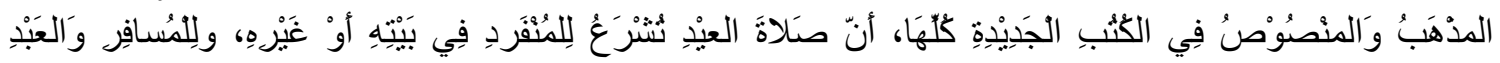

Terjemahannya: "Pendapat mazhab dan yang dinaskan (Imam syafi'i) dalam semua kitab-kitab (yang menukilkan) pendapat baru beliau, bahwasanya salat Id disyariatkan utk dilaksanakan secara personal di rumah atau selainnya, sebagaimana (disyariatkan) pula bagi musafir, budak dan wanita". ${ }^{5}$ (Raudhah at-Thalibin 2/ 70).

Al-Hajjawiy juga berkata:

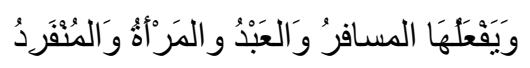

\footnotetext{
${ }^{3}$ Burhanuddin Mahmud bin Ahmad Al Bukhariy Al Hanafiy, Al Muhith Al Burhaniy fi Al fiqh Al Nu'maniy, Jilid II (Beirut, Dar Al Kutub Al Ilmiyah, 1424H/2004M) h.112

${ }^{4}$ Muhammad bin Ahmad 'Alisy Al Malikiy, Minh Al Jalil Syarh Al Mukhtashar Al Jalil, Jilid I (Beirut, Dar Al Fikri, 1409H/1989M) h. 467.

${ }^{5}$ Yahya bin Syaraf Al Nawawiy, Raudhah Al Thalibin wa Umdah Al Muftin Jilid 2 (Beirut, Al Maktab Al Islamiy, Cet. Ke 3, 1412H/1991M) h. 70
} 
Terjemahannya: Salat Id boleh juga dilakukan oleh musafir, budak, wanita dan munfarid (sendiri). ${ }^{6}$ (al-Iqnaa' $1 / 200$ ).

Kedua mazhab ini berlandaskan kepada qiyas salat Id kepada salat-salat nafilah dimana salat-salat tersebut tidak mempersyaratkan bahwa orang yang melakukannya harus berdomisili pada satu tempat (al-Istiithaan), sehingga hal ini menggugurkan syarat wajibnya berjamaah sebagaimana yang terdapat dalam salat Jumat, maka hal ini berlaku juga pada salat Id. ${ }^{7}$ (al-Mughni 2/ 291).

Adapun dalil mazhab Hanafiyah yang mendasari pendapat yang mengatakan tidak bolehnya melakukan salat Id secara personal dengan menqiyaskannya kepada salat Jumat dari sisi persyaratan berjamaah, maka dapat ditanggapi bahwa qiyas ini kelihatannnya dapat disanggah dengan adanya sisi perbedaan yang mencolok antara keduanya, diantaranya: Hukum asal pensyariatan kedua salat tersebut, tidak adanya persyaratan Istiithaan salat Id, status hukum khutbah yang berbeda di kedua salat tersebut, dan pensyariatan kepada orang yang tidak melaksanakan salat seperti wanita haidh untuk menghadiri salat ini, di mana hal ini tidak kita dapati secara khusus pada salat Jumat. ${ }^{8}$ (Bahr al-Mazhab 2/ 467).

Dari penjelasan ulama fiqih di atas dapat disimpulkan bahwa jumhur ulama selain Hanafiyah bersepakat dibolehkannya pelaksanaan salat Id secara personal baik bagi yang terlambat sehingga tidak mendapatkan salat bersama imam ataupun dikarenakan adanya uzur. Hal ini dalam hemat kami dapat dijadikan sebagai landasan dalam menetapkan pelaksanaan salat Id dalam masa sulit seperti ini.

\section{Hukum Pelaksanaan Salat Id secara personal dan terbatas di masa Covid 19}

Penjelasan dan pendapat jumhur ulama tentang kebolehan pelaksanaan salat Id secara personal atau bersifat terbatas seperti yang telah dijelaskan dalam pembahasan lalu merupakan solusi konkrit dalam pelaksanaan salat Id di masa pandemi Covid 19 saat ini, hal ini dapat diperkuat dengan mempertimbangkan beberapa alasan berikut ini:

1. Pelaksanaan Salat Id secara hukum asal lebih dekat kepada pelaksanaan salat-salat sunnah berjamaah lainnya, seperti salat Kusuf (gerhana), Istisqa dan yang lainnya, di mana salat salat ini sebagaimana dapat dilakukan berjamaah maka bisa juga dilaksanakan secara personal dan terbatas. ${ }^{9}$ (al-Umm, 1/ 260)

\footnotetext{
${ }^{6}$ Musa bin Ahmad Al Hajjawiy, Al Iqna' fi Fiqh Al Imam Ahmad bin Hanbal, Tahqiq Abdul Latif Muhammad Musa As Subkiy Jilid I (Beirut, Dar Al Ma'rifah t.t.t) h. 200

${ }^{7}$ Abdullah bin Ahmad bin Muhammad bin Quddamah Al Maqdisiy, Al Mughniy Li Ibni Quddamah, Jilid 2 (Mesir, Maktabah Al Qohirah, 1388H/1968M) h. 291

${ }^{8}$ Abdul Wahid bin Ismail Al Ruyyaniy, Bahr Al Madzhab Fi Furu’ Al Madzhab Asy Syafi 'iy, Tahqiq Thariq Fathiy Al Sayyid Jilid II (Beirut, Dar Al Kutub AL Ilmiyah, 2009M) h. 467

${ }^{9}$ Muhammad bin Idris Asy Syafi'iy, Al Umm, Jilid I (Beirut, Dar Al Ma'rifah, 1410H/1990) h. 260
} 
2. Kaidah bahwa segala perintah semaksimal mungkin dilakukan sesuai dengan kemampuan. Hal ini berdasarkan:

Firman Allah Ta'ala:

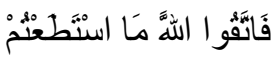

Terjemahannya: "Maka bertakwalah kepada Allah sesuai dengan kesanggupan kalian”. (QS. at-Taghaabun: 16)

Hadits:

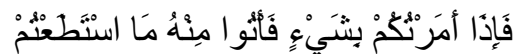

Terjemahannya: "Apabila aku perintahkan kalian satu perkara, maka lakukanlah sesuai dengan kemampuan kalian". ${ }^{10}$ (HR. Bukhari No. 7288 \& Muslim No. 1337)

Berdasarkan hal ini, ketika salat Id tidak dapat dilakukan dengan bersama jamaah kaum muslimin maka bukan berarti meninggalkan ibadah ini secara keseluruhan, tetapi melaksanakan ibadah ini sesuai dengan batas kemampuan yaitu melaksanakannya secara personal atau bersama keluarga inti di rumah dengan jumlah yang sangat terbatas.

3. Kaidah-kaidah yang berkaitan dengan menolak kemudharatan, diantaranya:

الضنَّرَر يُزَالْ

Terjemahannya: "Kemudharatan (harus) dihilangkan"."11 (al-Asybah wa anNadzaair, hal: 41)

الضَّرَرْ يُدْفعُع بقَفْر الإمكَكان

Terjemahannya: "Kemudharatan harus dicegah semaksimal mungkin".12 (Syarh al-Qawa'id al-Fiqhiyyah, hal. 207)

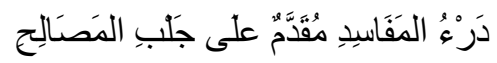

Terjemahannya: "Menolak mudharat lebih diutamakan daripada mengambil kemaslahatan". ${ }^{13}$ (al-Qawa'id al Fiqhiyyah wa Tathbiquha fi al Madzahib alArba'ah 1/ 238).

Kaidah-kaidah ini mempertegas bahwa di antara maksud dari pelaksanaan salat Id di rumah untuk menghindari dan mengantisiapasi kemudharatan yang bakal

\footnotetext{
${ }^{10}$ Muhammad bin Ismail Al Bukhariy, Shahih Al Bukhariy, jilid IX (Beirut, Dar Tauq Al Najah, 1422H) h. 94, dan Muslim bin Hajjaj Al Naisaburi, Shahih Muslim Jilid II, (Beirut, Dar Ihya' Al Turats Al Arabi, 1954 M.) h. 975

${ }^{11}$ Abdul Wahhab bin Taqiyyuddin Al Subkiy, Al Asybah Wa Al Nadzhair, Jilid I (Beirut, Dar Al Kutub Al Ilmiyah, Cet. 1, 1411H/1991M) h. 41

${ }^{12}$ Ahmad bin Al Syaikh Muhammad Al Zarqa, Syarh Al Qawa'id Al Fiqhiyyah, (Damaskus, Dar Al Qalam, Cet. Ke-2, 1409H/1989M) h. 207

${ }^{13}$ Muhammad Musthafa Al Zuhailiy, Al-Qawa 'id Al Fiqhiyyah wa Tathbiquha fi Al Madzahib AlArba'ah, Jilid I (Damakus, Dar AL Fkri, Cet. Ke-1, 1427H/2006M) h. 238
} 
terjadi jika salat Id dilakukan berjamaah baik di buka ataupun di lapangan terbuka dimana kontak sosial dalam segala bentuknya dalam suasana seperti hari Id sulit untuk dihindarkan.

4. Himbauan ulama baik secara personal ataupun kolektif untuk melaksanakan salat berjamaah lima waktu di rumah dan menggantikan salat Jumat dengan salat Dzuhur di rumah, bahkan sebagian telah menghimbau untuk tidak melaksanakan salat Id di Masjid atau di tempat terbuka lainnya. Himbauan dan fatwa ini seharusnya menjadi patokan umat dalam melaksanakan kegiatan beribadah mereka selama bulan suci Ramadhan dan pelaksanaan salat Id.

\section{Tata cara pelaksanaan Salat Id dan ibadah yang berkaitan di rumah dan dalam kondisi terbatas}

Adapun panduan pelaksanaan salat Id dan ibadah yang terkait di rumah dan dalam kondisi yang terbatas, dapat disimpulkan dalam beberapa poin berikut ini:

1. Secara umum mayoritas para ulama yang membolehkan berpendapat bahwa pelaksanaan Salat Id secara personal tidak berbeda dengan pelaksanaan salat Id berjamah, baik dari sisi jumlah rakaat, cara bertakbir dan begitu juga hal-hal yang lain dalam pelaksanaaan salat Id. Al-Baihaqi berkata:

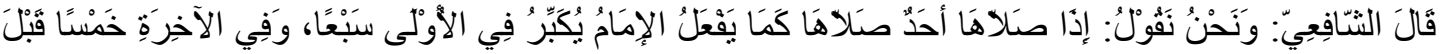

Terjemahannya: "Imam Syafi'i berkata: Dan kami berpendapat: JIka salat Id dilakukan oleh perorangan maka pelaksanaannya sama denganyang dilakukan oleh Imam (pada saat berjamaah), bertakbir tujuh kali di rakaat pertama dan lima kali di rakaat terakhir". ${ }^{14}$ (Ma'rifah as-Sunan wa al-Atsar 5/ 103).

Ibnu Qudamah setelah menukilkan perbedaan pendapat dalam tata cara mengqadha salat Id bagi yang ketinggalan, beliau berkata:

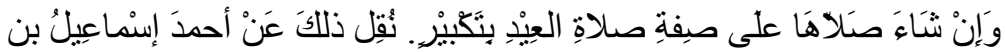

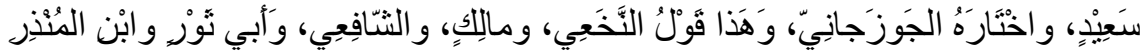

Terjemahannya: "Dan jika mau, ia boleh melaksanakannya sesuai dengan tatacara pelaksanaan salat Id yang disertai dengan takbir, pendapat ini dinukilkan dari Imam Ahmad oleh Ismail bin Said, dan menjadi pendapat yang dipilih oleh alJauzajaniy, dan ini merupakan pendapat an-Nakhaiy, Malik, as-Syafi'i, Abu Tsaur dan Ibn al-Mundzir". ${ }^{15}$ (al-Mughni, 2/ 290).

Tentang khutbah Id, maka menurut sebagian ulama hal ini tidak perlu dilakukan bagi yang salat Id secara personal. An-Nawawiy berkata:

\footnotetext{
${ }^{14}$ Ahmad bin Al Husain bin Ali Al Baihaqiy, Ma'rifat Al Sunan Wa Al Atsar, Tahqiq Abdul Mu'thiy Amin Qal'ajiy Jilid 5 (Beirut, Dar Al qutaiybah, Halab, Dar Al Wa'iy, Kairo, Dar Al Wafa', Universitas Islam Karachi Pakistan, Cet. ke-1, 1412H/1991M) h. 103

${ }^{15}$ Abdullah bin Ahmad bin Muhammad bin Quddamah Al Maqdisiy, Al Mughniy Li Ibni Quddamah Jilid 2 (Mesir, Maktabah Al Qohirah, 1388H/1968M) h. 290
} 


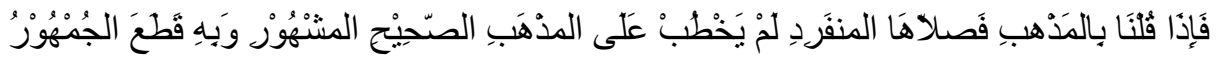

Terjemahannya: "Jika kita berpendapat sesuai pendapat mazhab, dan salat ini dilaksanakan secara personal maka ia tidak perlu berkhutbah menurut pendapat yang shahih dalam mazhab dan pendapat ini yang dipilih oleh jumhur (ulama Syafiiyah)". ${ }^{16}$ (al-Majmu' Syarh al-Muhadzdzab 5/2).

Dan pendapat ini yang dipilih dalam Fatwa ulama yang tergabung dalam Komisi Tetap Fatwa Arab Saudi berkaitan orang yang akan mengqadha salat Id ini:

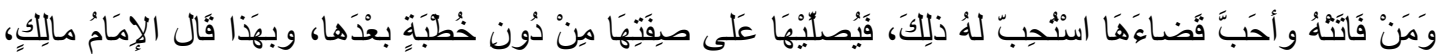

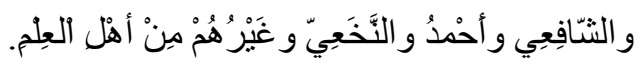

Terjemahannya: "Jika ia tidak mendapati salat Id dan ia ingin mengqadhanya maka hal ini dianjurkan, ia melakukannya sesuai dengan tatacaranya tanpa disertai khutbah setelah salat. Dan ini pendapat Imam Malik, Syafi'i, Ahmad, an-Nakhaiy dan ulama lainnya". ${ }^{17}$ (Fatawa al-Lajnah ad-Daimah 8/ 30)

2. Jika dalam satu rumah terdapat beberapa orang, maka dibolehkan salat berjamaah dengan keluarga inti di rumah tersebut selama semuanya berada dalam kondisi sehat. Dalil yang bisa dijadikan landasan adalah perbuatan sahabat Anas bin Malik Radhiyallahu'anhu-, sebagaimana yang dinukilkan oleh al-Bukhariy dalam kitab Shahihnya:

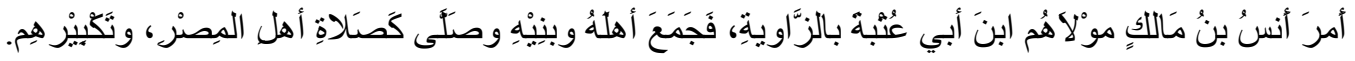

Terjemahannya: "Anas bin Malik yang tinggal di sudut (kota Basrah) mengumpulkan keluarga dan anak-anak belia, dan memerintahkan maula beliau Ibnu Abi Utbah (untuk menjadi imam) dan melaksanakan salat seperti pelaksanaan salat dan takbir penduduk kota". ${ }^{18}$ (Shahih al-Bukhariy, 2/ 23).

3. Adapun ibadah-ibadah yang terkait dengan pelaksanaan hari Id, maka tetap dilaksanakan sebagaimana petunjuk yang diajarkan, seperti diantaranya: Memperbanyak takbir sejak malam Id, menunaikan zakat fitrah sebelum salat Idul Fitri, mandi dan memakai wewangian dan pakaian yang terbaik, memakan kurma pada pagi hari sebelum pelaksanaan salat Idul Fitri dan yang lainnya.

Berkaitan dengan meminimalkan kemudharatan penyebaran Covid-19, maka semaksimal mungkin menerapkan social distancing atau physical distancing, sehingga sebaiknya menghindari untuk melakukan salaman dengan berjabat tangan secara langsung, berangkulan dan berpelukan, begitupula melakukan kunjungan ziarah antar keluarga, kerabat, tetangga dan handai tolan. Hal ini bisa diganti dengan mencukupkan dengan ucapan "Taqabbalallu minna waminkum" dan ucapan

\footnotetext{
${ }^{16}$ Yahya bin Syaraf Al Nawawiy, Al Majmu' Syarh Al Muhadzdzab, Jilid 5 (Kairo, Dar Al Fikri, t.t.t) h. 2

${ }^{17}$ Al Lajnah Al Da'imah lil Buhuts Al Ilmiyah wa Al Ifta', Fatawa Al Lajnah Al Da'imah, Disusun oleh Ahmad bin abdurrazzaq Al Duwaisy, Jilid 8 (Riyad, Idarah Al Buhuts Al Ilmiyah wa Al Ifta' - Al Idarah Al 'Amah li Al Thaba', t.t.t.) h. 30

${ }^{18}$ Muhammad bin Ismail Al Bukhariy, Shahih Al Bukhariy, jilid II (Beirut, Dar Tauq Al Najah, 1422H) h. 23
} 
selamat dan tahniah lainnya, baik secara lansung atau komunikasi telpon atau saling bersapa di media sosial. Adapun kegiatan kunjungan dan ziarah dapat diganti dengan saling bertukar hadiah dan makanan sebagai wujud ekspresi kegembiraan dan kesyukuran kita di hari yang mulia ini.

\section{KESIMPULAN}

Dari pembahasan dan pemaparan di atas dapat disimpulkan beberapa kesimpulan penting, diantaranya:

1. Hukum salat Id secara personal menurut jumhur ulama adalah boleh dan hukumnya sah, hanya madzhab Hanafiyah yang tidak memperbolehkan.

2. Hukum Pelaksanaan Salat Id secara personal dan terbatas di masa Covid 19 adalah boleh.

3. Salat Id dan ibadah yang berkaitan di rumah dan dalam kondisi terbatas dapat dilaksanakan dengan tata cara sebagaimana biasa ketika salat berjamaah, dan juga bisa dikerjakan secara berjamaah dengan keluarga inti di rumah.

\section{DAFTAR PUSTAKA}

Abdullah bin Ahmad bin Muhammad bin Quddamah Al Maqdisiy, Al Mughniy Li Ibni Quddamah, Jilid 2 (Mesir, Maktabah Al Qohirah, 1388H/1968M)

Al Baihaqiy, Ahmad bin Al Husain bin Ali, Ma'rifat Al Sunan Wa Al Atsar, Tahqiq Abdul Mu'thiy Amin Qal'ajiy Jilid 5 (Beirut, Dar Al qutaiybah, Halab, Dar Al Wa'iy, Kairo, Dar Al Wafa', Universitas Islam Karachi Pakistan, Cet. ke-1, 1412H/1991M)

Al Bassam, Abdullah bin Abdurrahman bin Soleh, Taudih Al Ahkam Min Bulughi Al Maram, Jilid III (Makkah Al Mukarramah, Maktabah Al Asadiy, Cet. Ke-5, $1423 \mathrm{H} / 2003 \mathrm{M})$

Al Bukhariy, Muhammad bin Ismail, Shahih Al Bukhariy, jilid IX )Beirut, Dar Tauq Al Najah, 1422H) h. 94, dan Muslim bin Hajjaj Al Naisaburi, Shahih Muslim Jilid II, (Beirut, Dar Ihya' Al Turats Al Arabi, 1954 M.)

Al Hajjawiy, Musa bin Ahmad, Al Iqna' fi Fiqh Al Imam Ahmad bin Hanbal, Tahqiq Abdul Latif Muhammad Musa As Subkiy Jilid I (Beirut, Dar Al Ma'rifah t.t.t)

Al Hanafiy, Burhanuddin Mahmud bin Ahmad Al Bukhariy, Al Muhith Al Burhaniy fi Al fiqh Al Nu'maniy, Jilid II (Beirut, Dar Al Kutub Al Ilmiyah, 1424H/2004M)

Al Lajnah Al Da'imah lil Buhuts Al Ilmiyah wa Al Ifta', Fatawa Al Lajnah Al Da'imah, Disusun oleh Ahmad bin abdurrazzaq Al Duwaisy, Jilid 8 (Riyad, Idarah Al Buhuts Al Ilmiyah wa Al Ifta' - Al Idarah Al 'Amah li Al Thaba', t.t.t.)

Al Malikiy, Muhammad bin Ahmad 'Alisy, Minh Al Jalil Syarh Al Mukhtashar Al Jalil, Jilid I (Beirut, Dar Al Fikri, 1409H/1989M) 
Al Maqdisiy, Abdullah bin Ahmad bin Muhammad bin Quddamah, Al Mughniy Li Ibni Quddamah, Jilid 2 (Mesir, Maktabah Al Qohirah, 1388H/1968M)

Al Nawawiy, Yahya bin Syaraf, Al Majmu' Syarh Al Muhadzdzab, Jilid 5 (Kairo, Dar Al Fikri, t.t.t)

Al Nawawiy, Yahya bin Syaraf, Raudhah Al Thalibin wa Umdah Al Muftin, Jilid 2 (Beirut, Al Maktab Al Islamiy, Cet. Ke 3, 1412H/1991M)

Al Ruyyaniy, Abdul Wahid bin Ismail, Bahr Al Madzhab Fi Furu' Al Madzhab Asy Syafi'iy, Tahqiq Thariq Fathiy Al Sayyid Jilid II (Beirut, Dar Al Kutub AL Ilmiyah, 2009M)

Al Subkiy, Abdul Wahhab bin Taqiyyuddin, Al Asybah Wa Al Nadzhair, Jilid I (Beirut, Dar Al Kutub Al Ilmiyah, Cet. 1, 1411H/1991M)

Al Syafi'iy, Muhammad bin Idris, Al Umm, Jilid I (Beirut, Dar Al Ma'rifah, 1410H/1990)

Al Zarqa, Ahmad bin Al Syaikh Muhammad, Syarh Al Qawa'id Al Fiqhiyyah, (Damaskus, Dar Al Qalam, Cet. Ke-2, 1409H/1989M)

Al Zuhailiy, Muhammad Musthafa, Al-Qawa'id Al Fiqhiyyah wa Tathbiquha fi Al Madzahib Al-Arba'ah, Jilid I (Damakus, Dar AL Fkri, Cet. Ke-1, 1427H/2006M)

Khusru, Muhammad bin Framurz Mulla, Durar al-Hukkam Syarh Ghurar al-Ahkam, Jilid I ( Beirut, Dar Ihya' Al Kutub Al Arabiyyah, t.t.t) 